\title{
"Forces for peace because of the magic in them": Processes of Anglo-Soviet musical exchange c.1959-1974
}

Isobel Thompson, University College London

\begin{abstract}
Musical histories of the Cold War frequently emphasise the impact of American musical tours to socialist countries and the 'weaponisation' of modernist music, supposedly representative of the cultural freedom exclusive to the capitalist West, against the strict confines of Socialist Realism. This narrative, however, denies the vast output of classical music from the USSR and the brilliance of Soviet classical musicians, who consistently dominated international music competitions. This paper explores the British reception of visiting Soviet classical musicians to the UK from a multi-layered perspective. Starting with an analysis of the ways Anglo-Soviet musical exchanges were carried out through official government agreements, it goes beyond the traditional political focus to highlight the hitherto neglected role of British impresarios Victor and Lilian Hochhauser in coordinating Anglo-Soviet musical exchanges, and their fundamental importance to the success of such performances in Britain. It also examines interactions between Soviet and British musicians, and the relevance of these relationships to cultural diplomacy more broadly. The final section explores how Soviet music was presented to British audiences in programme notes and received in the broadsheet press.
\end{abstract}

\author{
Abbreviations \\ London Symphony Orchestra: LSO \\ Royal Liverpool Philharmonic Orchestra: RLPO \\ BBC Symphony Orchestra: BBCSO \\ The Information Research Department: IRD \\ Foreign Office: FO \\ Foreign and Commonwealth Office (from 1968 onwards): FCO \\ Leonard Darke Collection, Royal College of Music, London: LD \\ Deryck Cooke Collection, Cambridge University Library: DC
}




\section{Introduction}

'I think [the Russians] felt, as I myself did increasingly, that the true value of exchanges was not for bringing people together, or for displaying goodwill or for promoting an ideology. First and foremost, 'The Cherry Orchard' and 'Hamlet', Britten's War Requiem and Shostakovich's Fifth Symphony were forces for peace because of the magic in them. To use them for political purposes, however fruitfully, was to diminish them.'

\section{Christopher Mayhew, Labour MP and Foreign Office Under-Secretary. ${ }^{1}$}

The Western premiere of Dmitrii Shostakovich's Twelfth Symphony at the Edinburgh Festival in September 1962 epitomises Mayhew's conception of 'the magic' that made successful cultural diplomacy possible, described in the quotation above. In the midst of rising international tensions and weeks before the onset of the Cuban Missile Crisis, the Symphony was performed by Britain's Philharmonia Orchestra under the baton of the illustrious Soviet guest conductor Gennadii Rozhdestvenskii. Shostakovich's career had been turbulent, marred by sporadic accusations of 'formalism' in the Soviet press. ${ }^{2}$ The Twelfth Symphony, however, was safer territory due to its overtly pro-Soviet subject matter. It is dedicated to the memory of the Bolshevik revolutionary Vladimir Lenin (subtitled 'The Year of 1917'), and is arguably one of Shostakovich's more accessible symphonies, a programmatic work depicting various scenes from the revolution. ${ }^{3}$

At first glance, Rozhdestvenskii's performance of Shostakovich's Twelfth Symphony was unsuccessful. The Daily Telegraph critic Donald Mitchell criticised the symphony's 'monumentally noisy scoring and a blatant simplicity of material and method'. ${ }^{4}$ Derision of this sort was to be expected from British critics, many of whom were critical of socialist realist art and its political associations. Nevertheless, despite the Symphony's negative reception, critics commended Shostakovich's talent as a composer. As Mitchell himself stated: 'this is not to insult Mr. Shostakovich but to express one's own alarm at the conviction with which a great talent can serve strange Gods.' ${ }^{5}$ In recognising Shostakovich's individual artistic voice, the composer was absolved from blame for the supposedly poor symphony, its faults attributed instead to Soviet doctrinal pressures. Thus, although the performance was intended to represent the high calibre of Soviet cultural production at large, the critics' opinions demonstrate a more nuanced approach towards Soviet culture. Musicians were not simply viewed as the public face of an adversarial regime; both audiences and critics admired their artistic brilliance, paving the way for a richer appreciation of Soviet classical music that would ultimately become the key arbiter of the success of such performances in Britain.

\footnotetext{
${ }^{1}$ Christopher Mayhew, A War of Words: A Cold War Witness (London: I. B. Tauris, 1998) p. 78.

${ }^{2}$ Laurel Fay, Shostakovich: A Life (New York: Oxford University Press, 2000) pp. 87-107.

${ }^{3}$ Gerald Seaman, note for The Philharmonia, 4 Sept. 1962.

${ }^{4}$ Donald Mitchell, The Daily Telegraph, 5 Sept. 1962.

${ }^{5}$ Ibid.
} 
Rozhdestvenskii's performance was one of many artistic exchanges negotiated between the UK and Soviet governments from 1959 until the end of the Soviet Union. ${ }^{6}$ A key administrator of these exchanges was Christopher Mayhew, mentioned above. Mayhew, a Labour MP and Foreign Office (FO) official, had been instrumental in the creation of the Information Research Department (IRD) as a subset of the FO in 1948, an ideologically driven project to organise Britain's propaganda defence against Soviet socialism. He continued to be deeply involved in negotiations regarding Anglo-Soviet cultural exchanges. His comment above epitomises the growing difficulties he encountered in the attempt to shoehorn culture, particularly classical music, into a rigid political framework. This paper examines Anglo-Soviet musical exchanges from c.1959-1974, eschewing the conventional, excessively politicised narratives of the 'cultural Cold War'. Instead, it emphasises the essential role played by non-state individuals in the proliferation of exchanges as well as considering the aesthetic qualities of music itself. The aesthetic theorist Roland Bleiker has argued that music offers 'new ways of representing and understanding political phenomena' - as a non-verbal, non-visual form of cultural representation, it possesses a unique capacity to express emotions and ideas 'outside of itself'. ' This paper argues that the music involved in these exchanges was itself politically important and thus crucial to their success. Giving primary consideration to the British response to Soviet music and musicians, it demonstrates the difficulty of imposing rigid political objectives on cultural exchanges. ${ }^{8}$ Ultimately, audiences appreciated great music for what it was, and continued to engage in complicated, nuanced ways with the political system it supposedly represented.

Couched in the intersection between musicology and Cold War history, much of the existing literature on Anglo-Soviet musical exchange is either subsumed into musical biographies or falls prey to the limitations that beset Cold War historiography. ${ }^{9}$ The journalistic propensity to focus on 'secret state' mythology (in the wake of revelations about covert funding for cultural organisations throughout the Cold War, such as the Congress for Cultural Freedom) is compounded by the tendency of revisionist Cold War historians to emphasise who is manipulating culture, rather than the transmission or reception of culture itself. ${ }^{10}$ This has led to an over politicisation of cultural phenomena during the Cold War, and a lack of research into the autonomous development of culture in this period. Only recently has the aesthetic turn in international political theory encouraged researchers to explore cultural representation

\footnotetext{
${ }^{6}$ Treaty Series No. 82: Agreement between the Government of the United Kingdom of Great Britain and Northern Ireland and the Government of the Union of Soviet Socialist Republics on Relations in the Scientific, Technological, Educational and Cultural Fields 1969-61 (December 1 1959).

7 Roland Bleiker, 'Of Things We Hear But Cannot See: Musical Explorations of International Politics', in Resounding International Relations, ed. by M. I Franklin (New York: Palsgrave MacMillan, 2005), p. 187.

${ }^{8}$ Further research on Soviet perspectives of Anglo-Soviet cultural exchanges would be welcomed to marry this with the British experience discussed in this paper.

${ }_{9}^{9}$ For biographies, see Fay, Shostakovich: A Life; Elizabeth Wilson, Rostropovich: The Musical Life of the Great Cellist, Teacher and Legend, (London: Faber and Faber, 2018); Cameron Pyke, Benjamin Britten and Russia, (Woodbridge: The Boydell Press, 2016).

${ }^{10}$ For such a narrative on the Congress for Cultural Freedom see Frances Stonor Saunders, Who Paid the Piper? The CIA and the Cultural Cold War, (London: Grants Books, 1999). For a critical evaluation of this 'secret state' narrative see David Caute, 'Foreword', in The Cultural Cold War in Western Europe 1945-1960, ed. by Scott-Smith and Krabbendam, (London: Frank Cass, 2003), p. i.
} 
(particularly non-visual forms such as music) on its own terms, rather than just a tool for political propagandists. ${ }^{11}$ Nor has socialist realist music figured strongly in analyses of Cold War cultural exchange due to the disproportionate focus on the promotion of American culture in the USSR. ${ }^{12}$ Aiko Watanabe highlights that much of the research on culture during the Cold War is still confined to exchange between the two superpowers - inadvertently reinforcing the traditional model of historiography due to its excessive focus on power relations between the US and the Soviet Union. ${ }^{13}$ Only a few attempts have been made to understand Britain's role in cultural exchanges, most notably by Pauline Fairclough in her study covering the years 1938$1948 .{ }^{14}$

To provide political context, the following section of this article explores how Anglo-Soviet cultural exchanges were negotiated as part of each government's broader Cold War strategy. The second section explores the role of individual impresarios and musicians in facilitating cultural exchanges, highlighting the personal connections which were required in order for cultural diplomacy to be successful. The third section considers the reception of Soviet music in Britain as articulated through programme notes and concert reviews.

The research shows that although the cultural agreements themselves were highly politicised affairs, those responsible for carrying out government mandated exchanges were not politically motivated, but concerned with making quality Soviet classical music more widely accessible throughout the UK. This approach, which explores how cultural exchanges operated at multiple levels of formality, demonstrates culture's inherent ability to transcend political and linguistic boundaries. Although cultural diplomacy clearly requires a personal element, the methodological difficulties involved in identifying and explaining seemingly 'trivial' activities (such as friendships between musicians) mean it is often absent from Cold War histories. Informal aspects of exchange are vulnerable either to being shoehorned into a reductive political framework, explained by larger 'structural' forces, or to being overlooked altogether. Although music was at the 'side-lines' of the broader Anglo-Soviet relationship, small-scale aspects of exchange reveal the complex interactions, mutual interests, and the quality of the culture itself that were all important achievements on the way to establishing post-war peaceful cooperation between the USSR and Great Britain.

\footnotetext{
${ }^{11}$ Bleiker, p.189.

12 See, for example, Danielle Fosler-Lussier, Music in America's Cold War Diplomacy, (Berkeley: University of California Press, 2015); David Caute, The Dancer Defects: the Struggle for Cultural Supremacy during the Cold War, (Oxford: Oxford University Press, 2003).

${ }^{13}$ See J. L. Gaddis, We Now Know: Rethinking Cold War History, (Oxford: Oxford University Press, 1997), pp. 281287 for an explanation of the 'cultural turn'. Also see Aiko Watanabe,'Cultural Drives by the Periphery: Britain's Experiences'. History in Focus, 2006.

${ }^{14}$ Pauline Fairclough, 'The 'Old Shostakovich': Reception in the British Press', Music and Letters, 88:2 (2002), pp. 266-296.; Pauline Fairclough, Twentieth-Century music and politics: essays in memory of Neil Edmunds, (Surrey: Ashgate, 2013).; Fairclough and Wiggins, 'Friendship of the Musicians: Anglo-Soviet musical exchanges 19381948', in Music, Art and Diplomacy: East-West Cultural Interactions and the Cold War, ed. by Mikkonen and Suutari, (Burlington, VT: Ashgate, 2016), pp. 29-47.
} 


\section{The 'weaponisation' of culture? Government perspectives on Anglo-Soviet musical exchange}

'We should do whatever we can to help breach the doctrinal façade of the pernicious doctrine of Socialist realism, a doctrine which is still strangling new ideas and experiment in all fields of artistic endeavour'.

\section{R. L. Speaight (FO Cultural Relations Department), $1963 .{ }^{15}$}

Prior to the establishment of the first Anglo-Soviet cultural exchange agreement in 1959, musical exchanges between Britain and the Soviet Union were infrequent and informal. Before the Second World War, even compositions by the USSR's most celebrated composer, Dmitrii Shostakovich, had seldom been heard in Britain. ${ }^{16}$ In the absence of formal agreements, musical exchanges in this period were initiated by British-Soviet 'friendship' societies, who arranged cultural events such as lectures, publications and screenings. ${ }^{17}$ Nevertheless, such societies never succeeded in bringing Soviet culture into the mainstream as they primarily appealed to so-called 'fellow travellers' who sympathised with Soviet socialism. ${ }^{18}$ By the 1940 s, however, Britain's wartime alliance with the Soviet Union inspired coordinated efforts by each government to promote their respective cultures and reinforce public support for their alliance after years of mutual hostility. The result was the popularisation of Soviet culture in Britain; by the early 1940s London was 'buzzing' with all-Russian concerts. ${ }^{19}$ As East-West relations soured after the war, British authorities wanted to eradicate the monopoly over cultural exchange held by 'friendship' societies, wary of their political associations. ${ }^{20}$ The societies were seen as a hindrance to Anglo-Soviet relations because they 'misled Russians about the state of affairs in Britain', reaffirming Soviet hostilities towards the UK and the capitalist West. ${ }^{21}$

Attempts to formalise Anglo-Soviet musical exchanges were, however, temporarily halted in January 1948, when the Soviet Central Committee Secretary, Andrei Zhdanov, publicly targeted Soviet composers for creating 'anti-democratic', formalist music that was too closely associated with the 'bourgeois decadent music of the contemporary west'.22 For a time, the cultural and ideological divisions between East and West were so entrenched that between 1946-1953 no musical exchanges occurred between the USSR and the UK whatsoever. ${ }^{23}$ By the mid-1950s, however, British officials sought once again to negotiate a cultural exchange programme to

\footnotetext{
15 TNA: BW 64/43, Memorandum on Anglo-Soviet Cultural Exchanges 1963.

${ }^{16}$ Fairclough, Old Shostakovich, p. 268.

17 Ibid, p. 269.

${ }^{18}$ Emily Lygo, 'Promoting Soviet Culture in Britain: The History of the Society for Cultural Relations Between the Peoples of the British Commonwealth and the USSR, 1924-1945', The Modern Language Review, 108:2 (2013), pp. 571-596.

${ }^{19}$ Fairclough, Old Shostakovich, p. 275.

${ }^{20}$ Lygo, 'Promoting Soviet Culture in Britain', p. 577.

${ }^{21}$ Mayhew, War of Words, p. 52.

22 In Evan Mawdsley, The Stalin Years: The Soviet Union, 1929-1955, (Manchester: Manchester University Press, 1998), p. 141.

${ }^{23}$ Fairclough, Twentieth Century Music, p. 39.
} 
alleviate political tensions, heightened by the Soviet invasion of Hungary in 1956 and the fallout from the Suez crisis of the same year. Their efforts bore fruit in 1959 with the signing of the first Anglo-Soviet cultural agreement - an inter-governmental contract that formalised cultural exchanges between Britain and the USSR in a range of fields from scientific cooperation to educational exchanges and musical tours. This ushered in a new era of formalised cultural exchange and a proliferation of concerts in Britain, which showcased Soviet music and musicians. ${ }^{24}$

Having witnessed the growing success of the USSR's international 'peace offensive' throughout the 1940s (which portrayed Soviet Socialism as inherently peaceful in contrast with the 'aggressive' and 'imperialistic' capitalist West), Mayhew recognised the need for Britain to establish an organised propaganda defence of its own. ${ }^{25}$ The IRD provided Government funding for large-scale cultural events between Britain and the USSR. ${ }^{26}$ These incipient exchanges were formalised in the first 1959 Anglo-Soviet Cultural Agreement signed by Prime Minister Harold Macmillan and Soviet premier Nikita Khrushchev in Moscow. The agreement was renewed biennially until the late 1980s. Its aims were to:

[Develop] understanding between the peoples of the Soviet Union and the United Kingdom [and to] promote in every possible way the increase in [cultural] tours [...] [and promote] the further improvement of relations between the two countries and thereby assist in reducing international tension. ${ }^{27}$

International cultural exchanges were traditionally operated by the British Council, a government organisation specialising in cultural and educational opportunities abroad. Soviet authorities, however, demanded that the contracts took place within formal intergovernmental agreements (which were described by one British cultural attaché as 'frequently circumscribed and rather artificial'28). ${ }^{29}$ In his memoirs, Mayhew recognised the pragmatic dimension to the cultural exchange programme:

We spoke warmly about Count Leo Nikolaevich Tolstoy and Robert Burns, David Oistrakh and Benjamin Britten, but our aims were political: we wanted to break down the isolation of the Soviet people from the West and to disrupt their ties with British communists and fellowtravellers. ${ }^{30}$

\footnotetext{
24 John Morison, 'Anglo-Soviet Cultural Contacts Since 1975' in Soviet-British relations since the 1970s, ed. by Duncan and Pravda, (Cambridge: Cambridge University Press, 1990), p. 168.

${ }^{25}$ Anonymous, The New York Times, 17 Dec. 1962.

${ }^{26}$ Mayhew, War of Words, p. 18.

${ }^{27}$ Treaty Series No. 82: Agreement between the Government of the United Kingdom of Great Britain and Northern Ireland and the Government of the Union of Soviet Socialist Republics on Relations in the Scientific, Technological, Educational and Cultural Fields 1969-61 (December 1 1959) p.6

28 TNA: BW 64/43, Assessment of Exchanges with the USSR 1961/63.

${ }^{29}$ Morison, 'Anglo-Soviet cultural contacts', p. 174.

${ }^{30}$ Mayhew, War of Words, p. 58.
} 
The Anglo-Soviet Agreement had wider international implications for Britain's Cold War agenda. Indeed, FO documents state that the agreement brought 'a measure of equality with other European and foreign countries (notably the United States, France and Italy...)' who negotiated their own bilateral cultural agreements with the USSR. ${ }^{31}$ Large-scale cultural events also provided an occasion 'around which other useful activity can be built', such as the opportunity for informal contacts with Soviet officials at embassy receptions. ${ }^{32}$ The agreement therefore allowed Britain to substantiate its relevance on the international stage and demonstrate its importance to the cultural crusade against communism.

The principle of reciprocity was central to Britain's efforts to increase and formalise cultural exchange. In a review of exchanges from 1961-63, the British cultural attaché Kenneth James stated that the agreement allowed Britain to 'horse-trade one cultural event or visit with another and thus secure a limited but important British cultural 'presence' in the Soviet Union'. ${ }^{33}$ Both British and Soviet officials insisted on reciprocity and viewed cultural exchange as a political quid pro quo. ${ }^{34}$ Indeed, James stated that '[reciprocity] must be the sheet anchor of our cultural work here and any attempt [...] to apply different British standards should be firmly resisted as a waste of time and energy'. ${ }^{35}$

British officials wanted to showcase their artists to the widest possible Soviet audience to promote the varied cultural output of a free society and break down the perceived cultural 'isolation' of Soviet citizenry. ${ }^{36}$ Their intentions are revealed in a memorandum regarding a tour of the Eastern bloc by the British National Youth Orchestra: 'the Foreign Office were interested in this proposal as, in addition to the musical impact, it was hoped that the players would be able to make contact with Soviet youth'. ${ }^{37}$ Thus, musical exchange was also perceived as a vehicle for initiating contact with Soviet citizens - especially young people - in the hope that they might come to view the West more favourably. The perception of cultural events based on their propaganda value underscores the government's highly pragmatic attitude towards culture and the political opportunities it provided.

When Prime Minister Edward Heath attended a festival of Soviet music in London in 1972, FO officials considered it a tactical gesture that would 'make it more difficult for the Russians to argue that we are showing hostility towards them'. This was a pragmatic move, certainly in the early stages of détente, which had been marred in 1971 by the British expulsion of 105 Soviet spies. ${ }^{38}$ Officials recognised that ' $w$ hatever its shortcomings, [Soviet leadership] attaches great

\footnotetext{
${ }^{31}$ TNA: BW 64/57, Memorandum on performing arts exchanges 1962/63.

32 Ibid.

33 Morison, 'Anglo-Soviet cultural contacts', p. 168.

${ }^{34}$ Ibid, p. 175.

35 TNA: BW 64/43.

${ }^{36}$ Mayhew, War of Words, p. 58.

${ }^{37}$ TNA: BW 64/44, Meeting to consider manifestations for USSR and Satellites 1961/62.

${ }^{38} \mathrm{Ibid}$.
} 
importance to achievements in the performing arts'. ${ }^{39}$ Such instances provided a substitute for formal diplomacy by validating the USSR's sense of superiority in the cultural sphere.

Despite a mutual understanding that 'cultural' agreements were inherently political, the notion that British culture could be weaponised for the 'embourgeoisement' of Soviet minds demonstrated politicians' underestimation of the rich and varied output of classical music from Russia (particularly from internationally renowned composers such as Chaikovskii, Rachmaninov, Rimsky Korsakov and Borodin, to name a few) and the Soviet Union. ${ }^{40}$ Soviet musicians also dominated international music competitions throughout the 1940 s and 50s, cementing their reputation for excellence. ${ }^{41}$ Despite their intentions, officials were unable to negotiate the musical aspects of the agreement without the help of professional impresarios. Ultimately, the rigid perception of culture as a foreign policy asset was not enough to guarantee the success of these exchanges; this would require a whole range of non-governmental actors, as subsequent sections of this paper will show.

\footnotetext{
39 TNA: BW 64/43, Kenneth James.

${ }^{40}$ Wilson, Mstislav Rostropovich, p. 178.

${ }^{41}$ See Kiril Tomoff, Virtuosi Abroad: Soviet Music and Imperial Competition during the early cold war: 1945-1958,

(London: Cornell University Press, 2015).
} 


\section{Musical interactions: impresarios and musicians during the Cold War}

'We were so grateful to have their artistry here, and they were happy to have people who understood their problems. Our relationship wasn't only commercial - we were heavily and deeply involved with these artists.'

\section{Lilian Hochhauser, 2010.42}

While government documents attest to the political motive behind musical exchanges, disproportionate reliance on these sources obscures the role of impresarios and musicians whose role in the administration and very substance of cultural exchange was fundamental to its success. Personal contacts based on a mutual appreciation of classical music reveals that individuals, and the quality of music itself, were vital to the flourishing musical exchanges. ${ }^{43}$ The aesthetic theorist, Roland Bleiker, has spoken of classical music's capacity to transcend linguistic and political boundaries and bring together people from disparate backgrounds. This aesthetic quality, described by Mayhew as the 'magic' of music, is also largely absent from studies of cold war cultural exchanges.

From a musical perspective, the idea of an equal, reciprocal relationship with the USSR was impractical and unsustainable. British politicians were ignorant of how important Russian music was to London's classical music scene. ${ }^{44}$ The sheer number of performances of Soviet compositions by the LSO throughout the 1960s suggests that exchanges had expanded beyond the narrow scope of tactical diplomacy. From 1950-59, the LSO only performed seven concerts containing works by Soviet composers. ${ }^{45}$ From 1960-69, however, there were fifty-four such performances, including works by Shostakovich, Kabalevskii, Khachaturian, Khrennikov and Miaskovskii. ${ }^{46}$ This is not to say that the cultural agreements did not provide British musicians with unprecedented opportunities; the prolific British composer Benjamin Britten's first visit to the USSR for the 1963 Festival of British Musical Art, for example, was stipulated by the agreement. ${ }^{47}$ However, the opportunities it provided, borne out of a desire for reciprocity, can more substantively be viewed as a point of departure for expanding musical contacts. The fact that visiting Soviet musicians to the UK consistently outnumbered British musicians to the USSR is symptomatic of a driving force behind exchange that requires greater explanation. ${ }^{48}$ The

\footnotetext{
42 Victor \& Lilian Hochhauser interview with Ismene Brown, 'TheArtsDesk Q\&A', The Arts Desk (2010), https://theartsdesk.com/classical-music/theartsdesk-qa-impresarios-victor-and-lilian-hochhauser-part-2, Accessed 2 March 2018.

${ }^{43}$ Giles Scott-Smith, 'Introduction: Private Diplomacy, Making the Citizen Visible', New Global Studies, 8:1 (2014), p. 6.

${ }^{44}$ Soviet musicians dominated international music competitions throughout the 1940s and 50s, cementing their reputation for excellence. See Kiril Tomoff, Virtuosi Abroad: Soviet Music and Imperial Competition during the early cold war: 1945-1958, (London: Cornell University Press, 2015).

${ }^{45}$ LSO performance data.

${ }^{46} \mathrm{Ibid}$. This figure excludes all LSO performances with Soviet soloists/conductors so in reality the post-1959 figure is much higher.

${ }^{47}$ Pyke, Benjamin Britten, p. 153.

${ }^{48}$ As already noted, FO officials consistently complained about the lack of reciprocity in exchanges.
} 
musicologist Peter Schmelz highlighted the need for a discussion of the 'least discussed types of Cold War musical experiences: musical encounters taking place outside of - or at the margins of - official cultural exchanges'. ${ }^{49}$ I will explore two such encounters, focusing on the 'productive' aspects of musical exchange by impresarios and musicians.

\section{Impresarios}

Until 1974 the British impresarios Victor and Lilian Hochhauser, held a 'virtual monopoly of Soviet cultural events in Britain'.50 Victor Hochhauser (born in Czechoslovakia in 1923) began staging concerts at London's Royal Albert Hall in the 1940s and had made a name for himself in musical circles by the time he married Lilian in 1949. Taking advantage of the cultural 'thaw' under Khrushchev after Stalin's death, the couple began to bring musical artists from the USSR to Britain. Conducting all major discussions with Soviet authorities in Moscow, the Hochhausers successfully coordinated negotiations between Goskontsert ${ }^{51}$, the Soviet embassy in London, the FO, musicians and concert venues. ${ }^{52}$ Whereas diplomats primarily liaised between the two governments, the multiplicity of contacts managed by the Hochhausers (in both English and Russian) highlighted their unique capacity for understanding the needs of Soviet ministries and managing the suspicions attached to Britons in the USSR at this time. The Hochhausers paid all expenses themselves, (within reason - the British Council often subsidised performances) such as artists' air travel, internal transport and accommodation. They also complied with more exorbitant Soviet demands, for example organising buses to visit Karl Marx's grave at Highgate and repairing performers' costumes. ${ }^{53}$ These details demonstrate the Hochhausers' ability to manage every facet of exchanges so as to please the Soviet authorities and ensure the successful continuation of musical exchanges despite the strained political relationship between governments.

By 1965, the Hochhausers' roster of Soviet artists included some of the world's most preeminent musicians and ballet companies. Data from the LSO shows the vast number of concerts promoted by the Hochhausers and the resulting opportunities for Soviet soloists and conductors to perform with the British orchestra; the pianists Sviatoslav Richter and Vladimir Ashkenazi, conductors Kirill Kondrashin and Gennadii Rozhdestvenskii and the cellist Mstislav Rostropovich all performed with the LSO on multiple occasions within a two-year period from $1961-3.54$

The Hochhausers also coordinated many debut appearances by Soviet musicians and orchestras in Britain. In September 1960, for example, they brought the Leningrad Symphony Orchestra to London's Royal Festival Hall, conducted by Evgenii Mravinskii and accompanied

\footnotetext{
${ }^{49}$ Peter Schmelz, "Shostakovich” Fights the Cold War: Reflections from Great to Small', Journal of Musicological Research, 34:2 (2015), pp. 107-8.

50 Letter from R. Speaight (TNA: BW 64/57).

51 The State Concert Committee of the USSR.

52 Pyke, Benjamin Britten, p. 162.

53 TNA: BW 64/57, letter from R. Speaight.

${ }^{54}$ LSO performance data
} 
by Shostakovich. It was the first visit of any Soviet orchestra in the UK - the Hochhausers would later go on to represent all the leading Russian orchestras. ${ }^{55}$ Their flair for negotiation is also evident in the Soviet repertoire they premiered in Britain. Mravsinskii had wanted to perform Shostakovich's Eighth Symphony (notoriously denounced as 'repulsive and ultra-individualist' by Soviet authorities ${ }^{56}$ ) with the Leningrad Philharmonic Orchestra at the Edinburgh Festival. ${ }^{57}$ Mravinskii implored Hochhauser to negotiate with the reluctant Soviet 'apparatchiki' (members of the Soviet Communist Party administrative system) who were eventually persuaded by Hochhauser that there was an appetite for the symphony in Britain. Thus, despite the political weight evidently attributed to classical music by Soviet authorities, Hochhauser's apolitical stance allowed him to circumvent Soviet propaganda concerns. The delicacy of this situation illustrates that the Hochhausers had built a reputation with the Soviet authorities for being trustworthy, reliable and most importantly, successful at coordinating concerts where Soviet musicians would be viewed by the largest audiences.

The personal and financial risks taken by impresarios to promote Soviet artists at the height of the Cold War should not be underestimated. Regardless of political circumstances, there were immense complexities and costs involved in organising transportation and visas for entire orchestras to travel to the UK. After the USSR's brutal suppression of the Prague Spring in 1968, Goskontsert cancelled many of their contracts with the Hochhausers. Thus, although there was credibility to be gained by conducting negotiations under official auspices, when diplomatic relations broke down impresarios incurred significant financial losses. ${ }^{58}$ Tensions climaxed in 1974, when Rostropovich and his family fled the USSR and settled, for a while, at the Hochhausers' home in London, having built a close personal relationship with the couple during previous visits to the UK. Following this, until 1991 the Hochhausers were personae non grata in the USSR and were forbidden to represent Soviet artists. Although this demonstrates the inescapable political framework in which the Hochhausers operated, the fact that they took such great risks to carry out their work (and accommodated Rostropovich despite the inevitable personal and financial repercussions) illustrates a less calculated and more informal side to musical exchange that is often overlooked in political histories.

The Hochhausers' position granted them the time to cultivate relationships with Soviet musicians while Anglo-Soviet diplomatic relations remained tense. "Our relationship wasn't only commercial," recalled Lilian Hochhauser, "we were heavily and deeply involved with these artists" ${ }^{59}$ Victor Hochhauser concurred: "We couldn't help it, talking with them almost every day on the phone, arranging their tours. [The Soviet violinist, David] Oistrakh [...] hated the system, and I think we may have been his closest friends anywhere". ${ }^{60}$ In contrast to the government's pragmatic motivations, the Hochhausers were driven by their passion for classical music and a genuine affinity with those who created it. By the late 1950s, they were the only people in Britain

\footnotetext{
55 'History: Victor and Lilian Hochhauser', Victor Hochhauser Presents, https://victorhochhauser.co.uk/page/4/HISTORY.php, Accessed on 3 January 2018.

${ }^{56}$ Mark Wigglesworth, "Notes on Shostakovich Symphony No.8", programme note (2005).

${ }^{57}$ TheArtsDesk Q\&A.

58 TheArtsDesk Q\&A.

59 Ibid.

60 Ibid.
} 
capable of managing artists, the cumbersome, often suspicious, Soviet bureaucracy, the British Government and concert venues. The fragility of this balance, successfully maintained for years by the Hochhausers, is epitomised by the dramatic decline in Anglo-Soviet musical exchanges after they took in Rostropovich. Without having the Hochhausers manage him, the Soviet pianist Sviatoslav Rikhter "simply refused to come to England altogether". ${ }^{61}$ Thus, the Hochhausers were not only unique in their capability to negotiate, but also in their ability to create genuine ties with Soviet artists.

The fundamental importance of the Hochhausers to cultural exchange is highlighted by the British government's complete reliance on them to conduct negotiations with Goskontsert and the Soviet Ministry of Culture. Displeased with the decline in musical exchange after 1974, Parastaev, the Soviet cultural attaché in London, asked for FCO assistance with impresarios. The response of John Morgan (Head of the British Cultural Relations Department) is worth noting:

There was no equivalent of Gosconcert in Britain. Impresarios played a key role here. We could not operate without them; they took a commercial risk and assumed a contractual obligation [...] Hochhauser had made a very significant contribution to our cultural relations and he had helped to widen the pleasure and experience of people in both our countries through the various cultural manifestations he had sponsored. We valued what he had accomplished. ${ }^{62}$

Morgan's gratitude towards Hochhauser reflects how the impresarios' work could be advantageous for the government. Hochhauser's assumption of financial and personal responsibility served to minimise any potential public objection to government spending on visits by Soviet artists. While measures were being taken by the government to protect against a Soviet nuclear missile attack, spending public money on hotels for Soviet musicians may well have proved unpopular. Crucially, therefore, the Hochhausers navigated political tensions as well as facilitating artistic exchange.

In assisting the government's diplomatic efforts, the Hochhausers encountered many obstacles, such as the constraints of suspicion, protocol and the desire for reciprocity. Merri Herrala, one of the few historians to have examined impresarios' role in facilitating East-West musical exchange, has argued that:

these sub-state actors had considerably more leeway behind the scenes of the cultural exchange processes between the superpowers than has previously been shown. While heads of state performed their usual public rituals, impresarios and performers were more privately negotiating [...] with 'weapons' far more practical and non-destructive. ${ }^{63}$

\footnotetext{
61 lbid.

62 NA BW 64/47.

${ }^{63}$ Merri Herrala, 'Pianist Sviatoslav Richter', in Music, Art and Diplomacy: East-West Cultural Interactions and the Cold War, ed. by Mikkonen and Suutari, (Burlington, VT: Ashgate, 2016), p. 90.
} 
Herrala's assessment, while important, nevertheless understates the role of impresarios. The term 'leeway' suggests that the impresarios functioned within a framework dictated by political authorities. On the contrary, sources have shown that the government overwhelmingly relied on impresarios to carry out exchanges. Herrala's use of the word 'weapons' also neglects the deeply personal relationships cultivated by the Hochhausers with their musicians. In light of the evidence presented in this section, it is unconvincing that they regarded their work as a 'weapon' of the Cold War. Paradoxically, what made the Hochhausers' cultural diplomacy so successful was the fact that they were driven not by politics, but a recognition of the brilliance of Soviet musicians and a desire to showcase their talents to the British public.

\section{Musicians}

Personal contacts between British and Soviet musicians, enabled by the Anglo-Soviet cultural agreements, were also crucial to successful cultural exchange and the development of classical music more broadly during this period. For example, Victor Hochhauser introduced the famous British composer Benjamin Britten to Rostropovich at the Royal Festival Hall in September $1960 .{ }^{64}$ An affinity soon developed between the pair. "After some discussion about the performance", recalled Victor Hochhauser, "Rostropovich said that he would like to come to the Aldeburgh Festival ${ }^{65}$ and asked me to make arrangements", highlighting the personal dimension required for genuine exchanges to flourish. ${ }^{66}$ By February 1962, Britten and Rostropovich were close friends, reflected in a letter by Britten regarding the Cello Suites he wrote for Rostropovich to be performed by them both as a duo recital:

It is difficult to write in a few words a description of my friendship and admiration for Slava Rostropovich. I was taken completely by his genius and personality when I heard him perform in London in September 1960 [...] I was determined immediately after this occasion to write something specially [sic] for him [...] Working with him was a joy. ${ }^{67}$

Britten's tone illustrates why the expressive properties of music itself are so critical to an assessment of Cold War cultural diplomacy. The spontaneous 'admiration' Britten felt for Rostropovich after hearing him perform could not have been engineered by diplomats; it depended instead on Rostropovich's own exceptional talent, which transcended the linguistic barrier that existed between himself and Britten. ${ }^{68}$ While the pair's friendship inevitably overlapped with diplomatic agendas, the attitudes and motivations of those in power must be differentiated from the spontaneous, genuine friendships forged between British and Soviet musicians. Susan Reid has criticised the reductive narrative of 'divisions, concealment and blocking' between East and West in Cold War histories, epitomised by Churchill's 'iron curtain'

\footnotetext{
64 Pyke, Benjamin Britten, p. 48.

${ }^{65}$ An annual classical music festival held in the Aldeburgh area of Suffolk, founded by Benjamin Britten in 1948.

66 Ibid, p. 296.

${ }^{67}$ Note for the LSO, 5 Jul. 1965.

68 Wilson, Mstislav Rostropovich, pp. 181-2.
} 
metaphor. ${ }^{69}$ In the cultural sphere, for example, there was scope for both musical exchange and friendships to flourish. This is epitomised by Britten enthusiastically composing for Rostropovich - an example of friendship nurturing a dynamic cycle whereby the more contact that took place, the more incentive there was for further creative exchanges between musicians.

The relationship between Britten and Shostakovich also provides a fresh perspective on Shostakovich's interactions with the West. Irina Shostakovich, the composer's third wife, emphasised the importance of music to Britten and Shostakovich's relationship stating that they "had a mutual interest in their creative work, in each other's music". ${ }^{70}$ Once again, we can identify the ability of music to engender emotional knowledge. This exemplifies Bleiker's assertion that the ability of instrumental music to relate to aspects outside of itself imbues it with political significance, challenging the tendency, particularly in international relations studies, to 'reduce the political to the rational'. ${ }^{71}$ For indeed, in the absence of a common language, it was the music itself that brought together musicians, impresarios and audiences alike. In 1972, Shostakovich visited Britten's Aldeburgh Festival but, according to Irina, 'The visit to Aldeburgh wasn't for the festival; Dmitri Dmitrievich and [Britten] just wanted to see each other'. ${ }^{72}$ In the context of his visits to the West, this more personal side to Shostakovich is rarely acknowledged; historians tend to focus on his reputation as the 'sacrificial lamb' of the Soviet regime at high-profile events. ${ }^{73}$ Nevertheless Shostakovich, too, had important and lasting contacts in the West irrespective of the severe political constraints he faced as a composer. For an edition of the British music magazine, Tempo, dedicated to Britten's 60 ${ }^{\text {th }}$ birthday in 1973, Shostakovich produced a handwritten note displaying his affection for the composer:

I warmly congratulate Benjamin Britten on his $60^{\text {th }}$ birthday. His beautiful compositions are loved throughout the whole world. I admire his inexhaustible creative energy. Britten is always at work, always making music. Dear Benjamin Britten, from the bottom of my heart I wish for you - one of my own favourite composers - the best of health, continued eminence, and creative success.

\section{Dmitri Shostakovich, Moscow, 30/VI/1973. ${ }^{74}$}

Referring to Britten as one of his 'favourite composers', Shostakovich demonstrated his individual tastes, rather than those to which he was expected to conform (Britten's modernism was practically the antithesis of socialist realism). His message encapsulated the ability of classical music to facilitate contacts between individuals in ways that could not be achieved by formal diplomacy alone. This was understood by the Hochhausers, whose successful

\footnotetext{
${ }^{69}$ Susan Reid, 'Foreword', in Music, Art and Diplomacy: East-West Cultural Interactions and the Cold War, ed. by Mikkonen and Suutari, (Burlington, VT: Ashgate, 2016), p. 1.

70 Pyke, Benjamin Britten, pp. 312-3.

${ }^{71}$ Bleiker, p. 188.

72 Pyke, p. 313.

${ }^{73}$ Francis Stonor Saunders, Who paid the piper?: the CIA and the Cultural Cold War, (London: Granta Books, 1999), pp. 50-51.

${ }^{74}$ Dmitrii Shostakovich, 'Benjamin Britten's Sixtieth Birthday.' Tempo Magazine.
} 
cultural exchanges were dependent on a careful balance of disparate interests, their ability to assume financial responsibility, as well as a genuine admiration for Soviet music. 


\title{
4. The reception of Soviet classical music in Britain
}

\begin{abstract}
"Perhaps music can tell us some surprising things that we can't find out from books and newspapers. The first thing of all to be said is that Americans and Russians simply love each other's music"
\end{abstract}

Leonard Bernstein, Moscow Conservatory, September 11, 1959. ${ }^{75}$

The following section uses programme notes and concert reviews as source material to explore the response of the British 'musical establishment' to visiting Soviet artists. As previously demonstrated, it required more than formal protocol and the narrow confines of political agreements to achieve Mayhew's aim of building bridges between British and Soviet citizens. The power of cultural representation itself was integral to transcending linguistic and political divides. The significance of non-political individuals to these exchanges has also been shown. These aspects of exchange not only resulted in friendships between cultural elites, but also a genuine fascination of and engagement with visiting Soviet musicians from British audiences. These performances provided a window into the USSR for both audiences and critics, eliciting a myriad of opinions.

\section{Programme Notes}

Concert programmes presented and articulated Soviet music to British audiences, providing an interpretation of the repertoire being performed, as well as biographical information about the composer, conductor and soloists. When Soviet musicians performed in Britain, programme notes were supplied by Soviet musicologists, portraying a distinctly socialist vision of classical music. When British orchestras performed music by Soviet composers, however, British experts wrote notes of their own. While programme notes by Soviet musicologists reveal the efforts made to use classical music as a propaganda weapon, British notes and reviews highlight the range of interpretations as the public attempted to make sense of Soviet high culture.

In 1960, the Leningrad Symphony Orchestra, accompanied by Dmitrii Shostakovich, was the first Soviet orchestra ever to visit the UK. Hochhauser's inaugural letter for the concert's programme demonstrates the role of programme notes in facilitating exchange. He lists the orchestra's awards (such as 'Merited Artists of the Republic' and 'State Order of the Red Banner of Labour') and states that its conductor, Evgenii Mravinskii, was a recipient of the Stalin Prize. ${ }^{76}$ As well as demonstrating to the audience that the Soviet musicians were highly talented, Hochhauser's letter showed that the USSR both recognised and rewarded outstanding classical music - an attempt to enhance its credentials amongst London's cultured elite and to demonstrate that a communist state could produce esteemed high-culture. Shostakovich's presence reinforced this official Soviet narrative, showing that he was still valued by the regime despite his past

\footnotetext{
${ }^{75}$ Schmelz, "Shostakovich" fights the Cold War', p. 91.

${ }^{76}$ Victor Hochhauser, programme for Leningrad Symphony Orchestra, 23 Sept. 1960.
} 
public vilification. ${ }^{77}$ The first work to describe the effects of Stalin's terror on cultural figures (as opposed to political rivals), Richard Anthony Leonard's A History of Russian Music, had been published only four years previously in $1956 .{ }^{78}$ These new revelations about the Stalinist era precipitated a more sympathetic view of Shostakovich in Britain than as merely the "chief cultural export of a hostile regime'. ${ }^{79}$

The programme's biography of Shostakovich and notes on his Eighth Symphony were translated from the Soviet musicologist and composer Boris Asaf'ev. Asaf'ev wrote that Shostakovich was 'profoundly patriotic [...] members of his family took part in the Russian revolution of 1905, themes on which have figured in several of his works'. ${ }^{80}$ The emphasis on the composer's devotion to his homeland, exemplified by his works dedicated to the revolution, was a concerted effort to highlight Shostakovich's loyalty to the regime. Asaf'ev's description of the Eighth Symphony is also significant. Hochhauser had secured the piece with some difficulty due to its denunciation by Soviet authorities, however, Asaf'ev wrote about it in glowing terms. His emphasis on its wartime context ("[a] tragic epic describing the terrible period of World War II, a period of heroic achievement and courageous endurance') cleverly evoked a more fruitful period of Anglo-Soviet relations as wartime allies. ${ }^{81}$

It is likely that programme notes, pre-written by Soviet musicologists, were part of the arrangement (coordinated by the Hochhausers) when Soviet musicians visited Britain. Asaf'ev's notes for the Eighth Symphony were carefully prepared to avoid mentioning its denigration in the USSR while substituting a reinterpretation that was compliant with Soviet ideology. Asaf'ev wrote of the Eighth:

Its great meaning lies in its ever throbbing reflection of the ideas that are constantly fostering and saturating art: only by breathing the atmosphere of the volcanic upheavals of his time can the artist really anticipate and create a new world of images drawn from reality. ${ }^{82}$

His notion that progressive music was 'drawn from reality' reflected a distinctly Soviet view of culture that equated 'progressive music' with its ability to transcend class distinction and portray the character of its time. This contrasted with the musical or technical criteria - such as flouting tonal or rhythmic convention - with which Western audiences would categorise 'progressive' or 'modern' music.

For Hochhauser's 'Festival of Rostropovich' at the Royal Festival Hall in 1965, programme notes were again written by the Soviet musicologist Lev Ginzburg, a contemporary of Rostropovich, whose writing echoed Asaf'ev's notes five years earlier. Ginzburg wrote: '[Rostropovich's]

\footnotetext{
${ }^{77}$ Fairclough, Old Shostakovich, p. 273. Despite public knowledge of Stalin's major political show trials in Britain, the fact that the purges in 1936-8 swept artists was less widely acknowledged.

${ }^{78}$ Richard Anthony Leonard, A History of Russian Music, (London: Jarrolds Publishers, 1956), pp. 284-293.

${ }^{79}$ Fairclough, Old Shostakovich, p. 281.

${ }^{80}$ Note for the Leningrad Symphony Orchestra, 23 Sept. 1960.

${ }^{81} \mathrm{lbid}$.

${ }^{82}$ Ibid.
} 
concerts [...] help to strengthen international cultural relations and serve the cause of world peace'. ${ }^{3}$ This demonstrated the USSR's determined effort to present itself internationally as a 'friendly' nation - part of its 'peace offensive' - a pertinent strategy in 1965 as America redoubled its military efforts in Vietnam. ${ }^{84}$ The idea that Rostropovich's concerts served the cause of 'world peace' reflected a typically Marxian conception of culture. According to this perspective, the relations of production in the USSR were reflected in its superior cultural output (in this case, Rostropovich's exceptional musical ability). While this diluted version of Marxist cultural doctrine was employed to 'foster interest in and sympathy for communism', the view that classical music should be widely accessible was popular - ironically - among conservative figures within the British musical establishment. ${ }^{85}$ This uniformity of opinion among Soviet musicologists, however, contrasted with the varied attitudes of their British counterparts.

Programme notes written by British musicologists reflected the growing debate over how Shostakovich's music should be viewed in the light of revelations about his treatment in the USSR. Some remained politically neutral in an attempt to extricate Shostakovich's music from its political context, adamant that the music should be able to speak for itself. These critics embraced classical music's ability to transcend ideological divisions and actively sought to disregard political boundaries. Notes for a performance of Shostakovich's Tenth Symphony in 1960 stated that '[Shostakovich's] relations with the State do not concern us this evening; it is his stature as one of the greatest (some would say the greatest) living symphonists. ${ }^{\prime 86}$ The author's assertion that Shostakovich's relations with the State had no bearing on his capabilities as a symphonist might today seem naïve with knowledge of the suffering he endured at the hands of the regime. Nevertheless, they were part of a pattern; Fairclough, for example, has identified a wider attempt among British critics at the time to establish a neutral platform for discussing Shostakovich's music. ${ }^{87}$ Notes for the RLPO's performance of the Tenth Symphony in 1960 state, 'Whatever one's attitude to recent Russian history, one should approach this work with the detachment shown by Beethoven's aristocratic patrons when they listened to the Sinfonia Eroica he composed in honour of their arch-enemy Napoleon. Music expresses the spirit of man, not an ideology. ${ }^{88}$ Ostensibly apolitical, these sentiments refuted any notion (conversely championed by Soviet musicologists) that the brilliance of Shostakovich's music was related to Soviet ideology. For many, Shostakovich's music engendered sympathy, provoking listeners to recognise his individual artistic voice despite the regime he publicly represented.

The range of British responses to Shostakovich's music is underscored by the attempts of some programme note writers to embrace the effect of Soviet ideology upon Shostakovich's music. Musicologist and broadcaster Deryck Cooke, for example, sympathised with Soviet 'criticisms', which he argued had encouraged positive improvements in Shostakovich's compositions,

\footnotetext{
${ }^{83}$ Note for the LSO, 5 Jul. 1965.

${ }^{84}$ Anonymous, The New York Times, 17 Dec. 1962

${ }^{85}$ Fairclough and Wiggins, 'Friendship of the Musicians', p. 29.

${ }^{86}$ Note for the BBCSO, 23 Aug. 1960.

${ }^{87}$ Fairclough, Old Shostakovich, pp. 271-3.

${ }^{88}$ Note for the RLPO, 1960.
} 
rendering them more accessible to the public. ${ }^{89}$ In his notes for Shostakovich's Fifth Symphony, Cooke wrote: 'we in the West are apt to condemn the official Soviet view of music, but its effect on Shostakovich has not necessarily been a harmful one. The Fifth Symphony is a far better work than the Third'..$^{0}$ Even Cooke could not fail to acknowledge the disconnect between Shostakovich and the regime, however: 'Soviet music theorists have had to accept this problematic side of Shostakovich's music, just because he is obviously their outstanding genius'. ${ }^{91}$

This narrow selection of British programme notes is reflective of the varied interpretations of Soviet classical music. While public interest in Soviet music was an important outcome of the agreement, the extent of the public's interest with musicians such as Shostakovich was entirely dependent on his music's ability to 'speak' to and be appreciated by audiences across the globe. In addition to programme note source material, concert reviews also demonstrate the level of public interest in Soviet classical music.

\section{Reviews}

Concert reviews, circulated in popular newspapers and divorced from the official channels of exchange, were a powerful tool for shaping public opinion. Despite public mistrust of the Soviet regime, critics rarely cast political judgement on Soviet musicians. Even less favourable reviews often associated the flaws in a work with Soviet dogmatism and remained resolutely sympathetic to the composers themselves.

Reviewing Shostakovich's Twelfth Symphony for The Daily Telegraph, Donald Mitchell lambasted its 'monumentally noisy scoring and blatant simplicity of material and method', which was 'not written for a gathering of individuals but for a mass audience of the faithful'. Despite this, he went on to say that 'this is not to insult Mr. Shostakovich but to express one's own alarm at the conviction with which a great talent can serve strange Gods. ${ }^{92}$ Mitchell remained sympathetic to Shostakovich, attributing the less-favourable aspects of the symphony to the 'uncivilised and anti-human' external pressures he faced, rather than Shostakovich's own talents. ${ }^{93}$ The Guardian's critic Colin Mason made similar accusations about the Eighth Symphony, arguing that "[Shostakovich] has certainly not had the encouragement or incentive [...] that he might have found in the different competitive conditions in the West. It may be that this is the real harm that his art has suffered from Soviet artistic demands. ${ }^{94}$ Again, Mason attributed the symphony's negative aspects to the lack of artistic 'competition' in the USSR, which supposedly prevented Shostakovich from achieving his full potential. Musicians themselves, therefore, were not always treated as an extension of the State in the way that Soviet authorities might have hoped.

\footnotetext{
${ }^{89}$ Fairclough, Old Shostakovich, p. 283.

90 Note for the LSO, 5 Mar. 1963.

${ }^{91}$ Note for the BBCSO, 24 Jul. 1961.

92 Mitchell, The Daily Telegraph, 5 Sept. 1962.

${ }_{93}$ Ibid.

${ }^{94}$ Mason, The Guardian, 24 Sept. 1960.
} 
Others sought to find more complex meaning in Shostakovich's works. John Warrack also reviewed Shostakovich's Eighth Symphony for The Sunday Telegraph, arguing that 'this is not quite the heroic-epic-poplar paean of the Soviet musicologists, so much as a tragic and powerful poetic appreciation of a people suffering and enduring war. A people: here is the eternal Russian feeling for masses having personality and will. ${ }^{95}$ Warrack rejected the Soviet musicological view, typified by Asaf'ev's programme notes for the Symphony, which regarded socialist realist symphonies to be inherently optimistic simply because they depicted socialist society. Warrack's perception of the Symphony reflected his personal understanding of (and sympathy for) individuals in the USSR. Unlike others who associated the shortcomings of Shostakovich's symphonies with Soviet dogmatism, Warrack appreciated the complex sentiment behind the Eighth Symphony and ascribed agency to the Soviet 'masses' that was often denied by other critics.

Warrack also observed visiting orchestras, attempting to 'make sense' of life behind the iron curtain at a time when the British public had limited knowledge about Soviet culture. According to Warrack, the Moscow Chamber Orchestra found it difficult to take 'simple instructions', which had to be 'conveyed laboriously through Russian section leaders as a piece of policy decision from the top' ${ }^{96}$ From the Bucharest State Orchestra, he 'felt a sense of iron control actually repressing a natural exuberance'. While these inferences were hardly intended to be empirical, they highlight the importance of cultural exchange in providing novel insight for Britons who had no other interaction with the USSR. While not always positive or sensitive, the range of these responses reveals the diverse, but nevertheless real, engagement with the music itself. The quality of the music was integral to this. As argued by Bleiker, 'the political significance of music lies in a more fundamental domain that transcends preconceived intellectual judgements: in the potential of all nonverbal and non-visual forms of knowledge to engender politically relevant knowledge'. ${ }^{77}$ While the 'knowledge' in this case was hardly empirical, nevertheless, the music encouraged British audiences to view the Soviet Union from a new perspective.

In contrast with the critics, when British audiences heard Shostakovich's music, they responded enthusiastically. Shostakovich was called to the stage five times after the performance of his Eight Symphony by the Leningrad Symphony Orchestra ('A night, this, to be remembered for many a year by the bright-eyed youngsters who were present', wrote one reviewer). ${ }^{98}$ No diplomat could factor such responses into the formal protocol of cultural diplomacy: audiences were drawn to Soviet music not because they had fallen for propaganda, or were passive dupes in some broader political strategy, but because they truly appreciated its importance and quality, irrespective of its origins. Lilian Hochhauser stated that 'hunger for things Russian was huge' during the cultural thaw following Stalin's death. ${ }^{99}$ That the music was so rapturously received illustrates the difficulty of using music as a cultural 'weapon'; it was unlikely that

\footnotetext{
${ }^{95}$ Warrack, The Sunday Telegraph, 22 Sept. 1963.

${ }^{96}$ Ibid.

${ }^{97}$ Bleiker, p. 180.

${ }^{98}$ Cater, The Daily Mail, 24 Sept. 1960.

99 TheArtsDesk Q\&A.
} 
audiences would imbue their perception of a brilliant performance with political opinion. Even critics who gave negative reviews admitted that the audience was enamoured. Having blasted Shostakovich's Twelfth Symphony as 'the crudest and most blatant symphony that I have ever heard' in 1962, Neville Cardus confessed that 'at the end of the performance the applause dwarfed even the violence of the Symphony'. 100

Audience engagement with Soviet music reveals the multiple processes through which exchange occurred. 'Exchange' was not just confined to political agreements but also encompassed public discourses and debates about Soviet classical music. Soviet musicologists seized the opportunity to popularise their own official narratives via the programme notes. British critics, however, offered their own interpretations by attempting to extricate composers from their political context or, alternatively, applauding the supposedly Soviet conception of art 'for the masses'. It is also significant, however, that poor reviews of Soviet performances generally remained sympathetic to the composer while negative aspects of a piece were attributed to official interference. Audiences, on the other hand, were less concerned with such debates. Their resounding acclaim for Soviet musicians and the warmth displayed towards them highlights that the success of cultural exchanges cannot be separated from the power of culture itself.

${ }^{100}$ Cardus, The Guardian, 7 Sept. 1962. 


\title{
5. Conclusion
}

Mayhew's initial objective of breaking down the supposed cultural isolation of Soviet people and disrupting their ties with British communists required more than formal protocol and political interactions. Politicians did not factor into their agreements the extent to which great music and talent, emanating from the Soviet Union at the time, could form a bridge between musicians and impresarios, leading to genuine friendships and fascination from audiences. Mayhew's changing attitudes towards the propagandising of high culture are worth revisiting at length:

\begin{abstract}
At the beginning, my interest in creating contacts with the Soviet Union had been entirely political. I had wanted to do something to weaken Soviet misconceptions about the West. But as time had gone on, as I made the acquaintance of leading British and Soviet actors, writers and musicians, my motivation began to change. I saw how easily great music, drama and literature leap national and ideological frontiers. On one occasion I witnessed a British audience acclaiming with genuine enthusiasm a performance of The Cherry Orchard by the Moscow State Theatre in Russian [...] How can an English audience respond so warmly to a play in Russian? It is because Chekhov and Shakespeare speak the same language. It is because great drama, literature, art and music reflect values which hold good for all peoples at all times. ${ }^{101}$
\end{abstract}

This paper demonstrates the limitations of viewing Anglo-Soviet interactions - and cultural diplomacy more broadly - solely in terms of formal, reciprocal exchange. Personal relations between cultural figures were essential for allowing exchange to flourish. Key figures in this context were Victor and Lilian Hochhauser, who were not only relied upon heavily by the government to carry out the practicalities of exchange agreements, but also by Soviet musicians as a source of friendship and hospitality outside of the USSR. Their devoted work, the visits of Benjamin Britten and the participation of various Russian classical musicians in Western concert tours and the efforts to depoliticise Soviet Socialist Realism by British musicologists all these were important achievements on the way to establishing peaceful post war cooperation between the USSR and the West.

Indeed, what brought these people together and sparked the interest of British audiences, journalists and musicologists alike was the music itself. The ability of classical music to draw together people from disparate cultural and linguistic backgrounds on the basis of shared emotion and feeling should not be understated. This paper highlights the importance of addressing the impact of emotions (often considered 'subjective and irrational') on international politics. ${ }^{102}$ It echoes the need for a semantic and methodological shift in the field of Cold War cultural exchanges, which can be assisted in conjunction with the developing field

\footnotetext{
101 Mayhew, War of Words, p. 78.

102 Bleiker, p. 180.
} 
of the politics of aesthetics. While there is certainly a historical congruence between music and politics that cannot be ignored; this research has demonstrated the value of exploring culture as an apolitical concept in helping to forge vital personal and professional ties across the iron curtain in the Cold War period. 


\section{Bibliography}

Anonymous, 'A Soviet 'Peace Offensive" The New York Times Archives (17 Dec. 1962)

Bleiker, Roland, 'Of Things We Hear But Cannot See: Musical Explorations of International Politics' in Resounding International Relations, ed. by M. I. Franklin (New York: Palsgrave MacMillan, 2015), (pp. 179-195)

Brown, Ismene, 'Theartsdesk Q\&A: Impresarios Victor and Lilian Hochhauser', The Arts Desk $<$ https://theartsdesk.com/classical-music/theartsdesk-qa-impresarios-victor-and-lilianhochhauser-part-2> [accessed 2 March 2018]

Cardus, Neville, 'Almost the End - a last message from Edinburgh', ProQuest Historical Newspapers: The Guardian and the Observer (1962)

Cater, Percy, 'A Classic Night to Remember', Daily Mail Historical Archive (24 Sept. 1960) Daily Mail Historical Archive

Caute, David, The Dancer Defects: the struggle for cultural supremacy during the Cold War (Oxford: Oxford University Press, 2003)

-. 'Foreword', in The Cultural Cold War in Western Europe 1945-1960, ed. by Scott-Smith and Krabbendam (London: Frank Cass, 2003)

Fay, Laurel E., Shostakovich: A Life (Oxford: Oxford University Press, 2000)

Fairclough, Pauline, Twentieth Century Music and Politics: Essays in Memory of Neil Edmunds (Surrey: Ashgate Publishing, 2013)

-. 'The 'Old Shostakovich': Reception in the British Press', Music \& Letters 88 (2007), 266-296

Fairclough, Pauline, and Louise Wiggins, 'Friendship of the Musicians: Anglo-Soviet Musical Exchanges 1938-1948', in Music, Art and Diplomacy: East-West cultural interactions and the Cold War, ed. by Mikkonen and Suutari (Burlington: Ashgate, 2016)

Fosler-Lussier, Danielle, Music in America's Cold War Diplomacy (Berkeley: University of California Press, 2015)

Gaddis, John Lewis, We Now Know: rethinking Cold War history (Oxford: Clarendon Press, 1997)

Herrala, Merri Elisabet, 'Pianist Sviatoslav Richter: The Soviet Union Launches a 'Cultural Sputnik' to the United States in 1960', in Music, Art and Diplomacy: East-West cultural interactions and the Cold War, ed. by Mikkonen and Suutari (Burlington: Ashgate, 2016), pp. 87-104.

'History: Victor and Lilian Hochhauser', Victor Hochhauser Presents <http://www.victorhochhauser.co.uk/page/4/HISTORY.php> [accessed 10 April 2018] 
Lygo, Emily, 'Promoting Soviet Culture in Britain: The History of the Society for Cultural Relations Between the Peoples of the British Commonwealth and the USSR, 1924-45', The Modern Language Review 108 (2013), 571-596.

Leonard, Richard Anthony, A History of Russian Music, (London: Jarrolds Publishers, 1956)

Mason, Colin, 'The London Cinema', ProQuest Historical Newspapers: The Guardian and the Observer (24 Sept. 1960)

Mawdsley, Evan, The Stalin Years: The Soviet Union, 1929-1955, (Manchester: Manchester University Press, 1998)

Mayhew, Christopher, A War of Words: A Cold War Witness (London: I. B. Tauris, 1998)

Mitchell, Donald. 'Anti-Human Symphony by Shostakovich', The Telegraph Historical Archive (5 Sept. 1962)

Morison, John, 'Anglo-Soviet cultural contacts since 1975' in Soviet-British Relations Since the 1970s, ed. by Pravda and Duncan (Cambridge: Cambridge University Press, 1990), pp. 168-192

Pyke, Cameron, Benjamin Britten and Russia, (Woodbridge: The Boydell Press, 2016)

Reid, Susan E., 'Foreword', in Music, Art and Diplomacy: East-West cultural interactions and the Cold War, ed. by Mikkonen and Suutari (Burlington: Ashgate, 2016)

Saunders, Frances Stonor, Who paid the piper?: the CIA and the Cultural Cold War (London: Granta Books, 1999)

Schmelz, Peter J., "Shostakovich" Fights the Cold War: Reflections from Great to Small', Journal of Musicological Research, 34 (2015), 91-140

Scott-Smith, Giles, 'Introduction: Private Diplomacy, Making the Citizen Visible', New Global Studies, 8 (2014), 1-7.

Shostakovich, Dmitri, ‘Benjamin Britten's Sixtieth Birthday’, Tempo Magazine 106 (1970), 1-4

Tomoff, Kiril, Virtuosi Abroad: Soviet Music and Imperial Competition During the Early Cold War: 1945-1958, (London: Cornell University Press, 2015)

Treaty Series No. 82: Agreement between the Government of the United Kingdom of Great Britain and Northern Ireland and the Government of the Union of Soviet Socialist Republics on Relations in the Scientific, Technological, Educational and Cultural Fields 1969-61 (December 1 1959) 
Warrack, John, 'The Style is the Country', Telegraph Historical Archive (22 Sept. 1963)

Watanabe, Aiko, 'Cultural drives by the periphery: Britain's experiences', History in Focus < https://archives.history.ac.uk/history-in-focus/cold/articles/watanabe.htmls [accessed 04 April 2018]

Wigglesworth, Mark, 'Mark's notes on Shostakovich Symphony No.8.', Mark Wigglesworth https://www.markwigglesworth.com/notes/marks-notes-on-shostakovich-symphony-no-8/ [accessed March 14, 2018]

Wilson, Elizabeth, Mstislav Rostropovich: Cellist, Teacher, Legend (London: Faber \& Faber, 2011)

\section{Unpublished Primary Sources}

\section{Programme Notes:}

"A Festival of Rostropovich." London Symphony Orchestra at the Royal Festival Hall. Programme notes. 5 July 1965. LD: 1964-66.

BBC Symphony Orchestra at Royal Albert Hall. Programme notes. 23 Aug. 1960. DC: Box 1 (Archive box 7): 1953-1964.

BBC Symphony Orchestra at Royal Albert Hall. Programme notes. 24 July 1961. DC: Box 1 (Archive box 7): 1953-1964.

Leningrad Symphony Orchestra at the Royal Festival Hall. Programme notes. 23 Sept. 1960. LD, 1964-66.

London Symphony Orchestra at Royal Festival Hall. Programme notes. 5 March 1963. DC: Box 1 (Archive box 7): 1953-1964.

Royal Liverpool Philharmonic Orchestra at Philharmonic Hall, Liverpool. Programme notes. 22 March 1960. DC: Box 1 (Archive box 7): 1953-1964.

Philharmonia Orchestra at Usher Hall, Edinburgh. Programme notes. 4 Sept. 1962. DC: Box 1 (Archive box 7): 1953-1964.

\section{Government Documents:}

TNA: BW 64/43: Cultural Agreement 1961/63

TNA: BW 64/44: Cultural Agreement 1961/63

TNA: BW 64/47: Musical exchanges and performances (confidential papers)

TNA: BW 64/57: UK-USSR Cultural Agreement 1963-1965 (confidential papers)

\section{Performance Data:}

London Symphony Orchestra performance schedule (1945-65). Accessed through personal correspondence with the LSO. 